\title{
新生児ラット膵単層培養 $\mathrm{B}$ 細胞の灌流
}

—-Deoxy-2-fluoroglucose の効果——

\author{
兵庫医科大学病院 \\ 中央臨床検查部 \\ 若林茂, 香川昌平 \\ 中尾啓子, 松岡瑛 \\ Perifusion of Monolayer-Cultured B Cells of Neonatal Rat Pancreases \\ - Effect of 2-Deoxy-2-Fluoroglucose -

\section{Shigeru WAKABAYASHI, Shohei KAGAWA, Keiko NAKAO and Akira MATSUOKA} \\ Department of Clinical Pathology and Clinical Laboratory, \\ Hyogo College of Medicine, \\ Nishinomiya, Japan
}

The effects of 2-deoxy-2-fluoroglucose in promoting the function of neonatal rat pancreatic B cells in vitro are presented. Functional studies of insulin secretion were carried out by perifusion procedures. At day 0 of culture, B cells showed a minimal monophasic insulin secretion in response to a $16.7 \mathrm{mM}$ single dose of glucose, whereas in the presence of $10 \mu \mathrm{M}$ forskolin or $1 \mathrm{mM}$ 3-isobutyl-1-methylxanthine, the same dose of glucose stimulated insulin secretion in a biphasic fashion. In contrast, after 7 days of culture in medium supplemented with $1 \mathrm{mM}$ 2-deoxy-2-fluoroglucose, B cells showed an adult-like biphasic pattern regardless of the presence of forskolin or 3-isobutyl-1-methylxanthine. In addition, the stimulatory effect of either leucine or 2-ketoisocaproate was also significantly increased, when compared to that of B cells at day 0 . Furthermore, when exposed to a linear gradient stimulation by glucose, these competent B cells secreted insulin in a dose-dependent fashion.

Moreover, in cultures supplemented with 2-deoxy-2-fluoroglucose the basal or stimulating levels of cAMP were about 20 -fold higher than at day 0 .

In conclusion, the data presented here demonstrate that the function of neonatal $B$ cells matures during culture, and suggest that this effect of 2-deoxy-2-fluoroglucose may be mediated by activation of either adenylate cyclase or catabolic enzymes of amino acids in B cells.

\section{I 緒 言}

新生児ラット膵内分泌細胞の単層培養に際し，酵素処理によって単離した膵細胞は培養中に再凝 
集し, 島状の内分泌細胞集団を形成する。この培養系では, 内分泌細胞間の本来の相互関係が比較 的保持された状態で培養可能とされ, また, in vivo 実験において不可避な個体差・飼育環境から 生ずる実験誤差を最小限に抑えることができる等の利点を有し, 新生児ラット荤単層培養は内分泌 細胞の機能・形態研究に少なから妋微を果してきた。しかし，この初代培養系における線維芽細 胞の旺盛な増殖は，培養環境を悪化させ，茀島細胞の萎縮・機能低下をもたらし，比較的長期にわ たる培養細胞の生活動態の研究を困難なものにしている。したがって, この培養系からの線維芽細 胞の除去は, 内分泌細胞研究の Key stepであり, これまで数多くの研究者によって種々の考案がな されてきた ${ }^{7)}$ 。

著者らは, 2-deoxyglucose ${ }^{293939}, 2$-deoxy-2-fluoroglucose ${ }^{33) \text { 37 40) }}$ 3-amino-3-deoxyglucose ${ }^{33)}$ お よび iodoacetic acid ${ }^{30}$ 等の培養液への添加が, 線維芽細胞の選択的除去並びにB 細胞の生存・機能 維持に有益であることを静置実験の成績より明らかにした。静置実験法は，インスリン分泌機能の 定量的な解析に有用であるが, インスリン分泌応答が単一相ではなく, 多相的・動的性格を有して いるために, 2-deoxyglucose 等の添加培養の際にみられる B 細胞機能変化を静置実験の結果からの み評価し, 結論を引き出すには限界がある。著者らは, B 細胞の glucose 等各種栄養物質刺激に対 するインスリン分泌応答の培養期間中における推移を更に明らかにする目的で新生児ラット荤単層 培養 $\mathrm{B}$ 細胞の灌流実験を実施し，その分泌応答を動的に把握し検討を加えた。

\section{II 実験材料および方法}

\section{1. 試薬}

Collagenase (type I ), 2-ketoisocaproate (KICA), calf thymus DNA は Sigma, trypsine (1: 250)はDifco, 2-deoxy-2-fluoroglucose, forskol in は Calbiochem-Behring, 3-i sobutyl-1-methylxanthine (IBMX) はAldrich, TCM 199 (glucose 不含) は日水製薬, 牛胎児血清 (FBS) はFlow, ラット・インスリンはNovoよりそれぞれ購入した。また, インスリン・アッセイ・キットはダイナ ボット，cAMPアッセイ・キットはヤマサ醬油より購入した。Glucose, leucineおよびその他の試 薬は和光純薬の製品を使用した。

\section{2. 新生児ラット膵島細胞の単層培養}

生後 3〜 4 日の SD 系ラット腪より摘出した膵組織を, Lambert et al. ${ }^{19}$ の方法に従い collagenase と trypsineによる酵素消化を施し，採取した単離細胞を glucose $16.7 \mathrm{mM}$, FBS 10\%を含む TCM 199により培養した ${ }^{25}$ 。培養20時間後, 組織培養用プラスチックシート ( Lux, $43 \times 50 \mathrm{~mm}$ ：灌 流実験用)およびプラスチック培養容器 (Falcon, \#3001：cAMP 測定用) に細胞を $1 \times 10^{6} \mathrm{cell} \mathrm{s} / \mathrm{ml}$ の密度で植え換え, 同じ組成の培養液を用いて 24 時間培養した（Day 0)。次いで, glucose $5.5 \mathrm{mM}$ あるいはglucose $5.5 \mathrm{mM}+2$-deoxy-2-fluoroglucose $1 \mathrm{mM}$ を含むTCM 199にて 7 日間培養を継続 した（Day 7 )。尚，培養液は灌流実験に供する迄に $2 \sim 3$ 度交換した。

\section{3 . 灌流実験}

灌流実験はKawazu et al. ${ }^{16)}$ の方法に従って実施した。培养細胞を含むプラスチックシート 2 枚 を直径 $3.5 \mathrm{~cm}$ の円形ホールをもつ肉厚 $3.5 \mathrm{~mm}$ のシリコンラバー・ガスケットの両側にセットし,

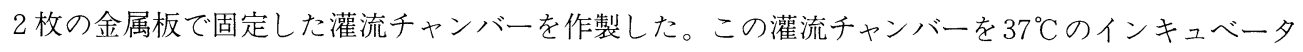
一に収め, 2 本のテフロン製細管 (内径 $1 \mathrm{~mm}$ ) の一方から glucose-free, FBS 0.5\%を含む TCM 199 を20分間導入し灌流システムを安定化させた後，種々インスリン刺激物質を含むTCM 199 を 30 
分間導入し本灌流を行った。次いで，再び前灌流液に戻して 20 分間の後灌流を行った。また， 0.33 $\mathrm{mM} / \mathrm{min}$ の濃度勾配をもつglucoseによる50分間の灌流を併せて行った。灌流速度は $0.5 \mathrm{ml} / \mathrm{min}$ に 設定し, 灌流液は 2 分毎にフラクションコレクターにて分画採取した。また灌流サンプルは測定直 前までー $20^{\circ} \mathrm{C}$ に保存し, インスリン濃度はラット・インスリンを標準としてRIA ビーズ固相法によ り測定した。

\section{4. $\mathrm{cAMP}$ 放出および細胞内 $\mathrm{cAMP}$ 量の測定}

培養細胞を刺激物質を含まない $1 \mathrm{ml}$ の TCM 199で30分間プレ・インキュベーション後, $10 \mu \mathrm{M}$ forskolin, $1 \mathrm{mM}$ IBMX 存在・非存在下で, glucose $16.7 \mathrm{mM}$ を含むTCM $1991 \mathrm{ml}$ を加え, 30分 間, $37^{\circ} \mathrm{C}$ でインキュベーションした。反応終了後, 直ちに培養液を採取する一方, 培養容器に $6 \%$ トリクロロ酢酸 $1.2 \mathrm{ml}$ を加之, 水飽和エチルエーテルで数回洗浄を繰り返した後, 凍結乾燥した。 cAMPサンプルはー $20^{\circ} \mathrm{C}$ で保存し, cAMPアッセイ・キット（RIA 法）を用いて測定した。cAMP 量は，それぞれの細胞内DNA 量により補正した。

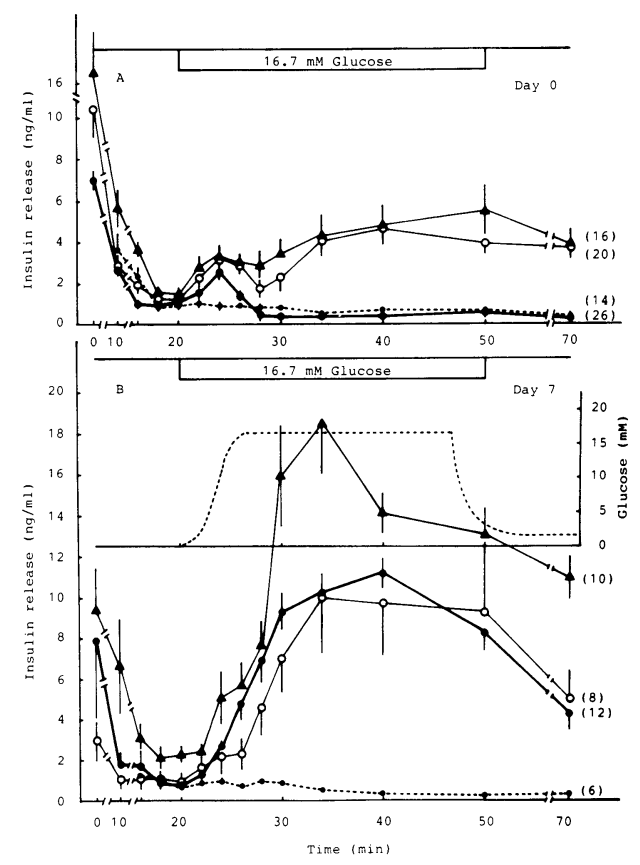

Fig. 1. Time course of insulin release with a square-wave glucose stimulation.

Monolayer islet cells at culture day 0 (A) or those that had been cultured for 7 days with $5.5 \mathrm{mM}$ glucose supplemented with $1 \mathrm{mM} 2$ deoxy-2-fluoroglucose (B) were exposed to stimulants for 30 min after the first 20 -min perifusion with nonstimulatory medium. Each point is the mean \pm SEM of $6 \sim 26$ experiments shown in the figure.

$0 \mathrm{mM}$ glucose,

- $16.7 \mathrm{mM}$ glucose,

A $16.7 \mathrm{mM}$ glucose +10 $\mu \mathrm{M}$ forskolin, $\longrightarrow 16.7 \mathrm{mM}$ glucose $+1 \mathrm{mM}$ 3-isobutyl-1-methylxanthine] 

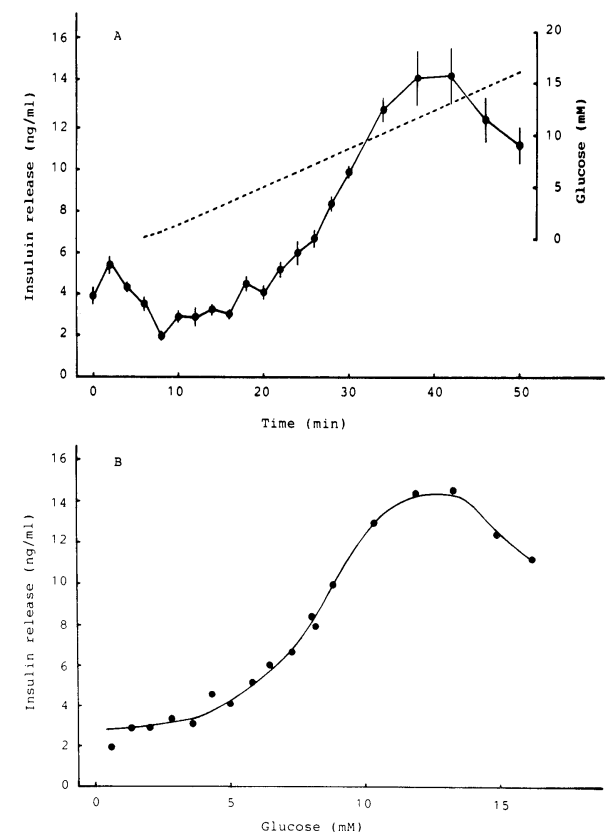

Fig. 2. Time course of insulin release with a linear gradient glucose stimulation and dose-response curve for insulin release.

Monolayer islet cells that had been cultured in medium with 5.5 $\mathrm{mM}$ glucose supplemented with $1 \mathrm{mM}$ 2-deoxy-2-fluoroglucose for 7 days (A) were exposed to a $0 \sim 15 \mathrm{mM}$ glucose linear gradient. The doseresponse curve was estimated from the data in Fig. 2A (Fig. 2B). Each point shows the mean \pm SEM of 5 experiments.

\section{DNA の測定}

培養細胞の DNA 量は, Fujimoto et al.のmicrofluorometric 法により, calf thymus DNA を標 準として測定した ${ }^{6)}$ 。

\section{6 . 統計学的処理}

実験成績はすべて, 平均值土標準誤差により表現し, 各実験グループ間の有意差検定は Student t-testにより行った。

\section{III 成 績}

\section{1. 灌流実験}

（1）2-Deoxy-2-fluoroglucose 添加培養 B 細胞のインスリン分泌動態

a) Glucose の効果： 前灌流開始直後にみられる高いインスリン分泌は, 本灌流開始前には約 $1 \mathrm{ng} / \mathrm{ml}$ にまで低下し，以後50分間の刺激物質を含まない灌流期間のインスリン濃度は，0.5 1.0 $\mathrm{ng} / \mathrm{ml}$ の基礎分泌レベルを維持した。尚，この灌流初期の高いインスリン值は，灌流液を充満する

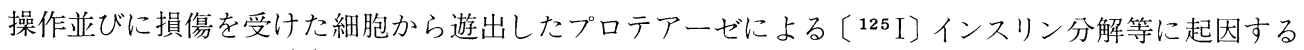
人為的なものである ${ }^{16)}$ 17) 
Day 0 の培養 B 細胞は, glucose $16.7 \mathrm{mM}$ による灌流開始後 4 分に $2.6 \mathrm{ng} / \mathrm{ml}$ の頂值を有し, 10 分 以内に終了する一過性のインスリン分泌を示すにすぎず，後期相分泌は認められなかった。一方， 2-deoxy-2-fluoroglucose 添加培養した Day 7 の培養 B 細胞は, 持続的なプラト一様後期相分泌を 伴ったインスリン分泌動態を示した。この培養 B 細胞からの初期相並びに後期相分泌については明 確に区別されず, 刺激開始後 4 分頃からインスリン分泌は急激に増大し，10～30分の後期相分泌期 間に8.2 11.2 $\mathrm{ng} / \mathrm{ml}$ の高值を維持した。また, forskolinあるいはIBMXは, それぞれ $10 \mu \mathrm{M}, 1 \mathrm{mM}$ の添加濃度でDay 0 の培養細胞からglucose 刺激に対応するインスリン分泌を促進し, 約 $4 \mathrm{ng} / \mathrm{ml}$ の安定したレベルの後期相分泌を誘起した。しかしながら, 2-deoxy-2-fluoroglucose 添加培養 B 細胞においては, forskolinの添加はglucoseによる後期相分泌を有意に増大させたが, IBMXはglucose 刺激効果に影響を与えなかった（Figs. $1 \mathrm{~A} ， 1 \mathrm{~B}$ )。

灌流液の glucose 濃度を $0 \sim 18 \mathrm{mM}$ まで直線的に変化させた濃度勾配刺激に対し, Day 7 の-deoxy-2-fluoroglucose 添加培養細胞は刺激開始後16１8分頃よりインスリン分泌応答を開始し，40分 後に頂值に達した (Fig. $2 \mathrm{~A})$ 。この結果から作成したglucose一インスリンの用量反応曲線は S 字状 を呈し, “Km" 值は $8 \mathrm{mM}$-glucose と算出された（Fig. 2 B)。

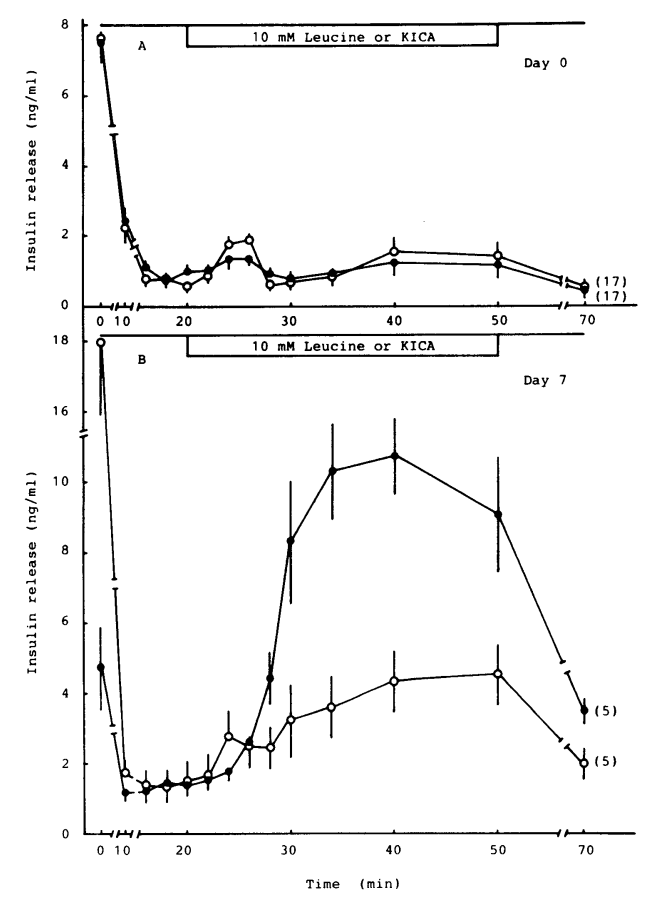

Fig. 3. Time course of insulin release with a square-wave stimulation by leucine or 2-ketoisocaproate (KICA).

Monolayer islet cells at culture day 0 (A) or those that had been cultured for 7 days with $5.5 \mathrm{mM}$ glucose supplemented with $1 \mathrm{mM} 2$ deoxy-2-fluoroglucose (B) were exposed to stimulants for $30 \mathrm{~min}$ after the first 20 -min perifusion with nonstimulatory medium. Each point is the mean \pm SEM of $5 \sim 7$ experiments shown in the figure. $[\bullet 10$ $\mathrm{mM}$ leucine, $\stackrel{\longrightarrow}{\longrightarrow} 10 \mathrm{mM}$ 2-ketoisocaproate (KICA)] 


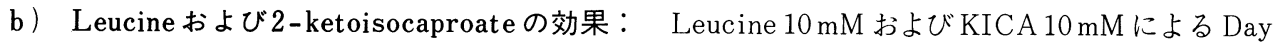
0 の培養細胞のインスリン分泌応答は，基礎分泌レベルを微かに増大させるにすぎなかった。しか し，2-deoxy-2-fluoroglucose 添加培養したDay 7 の B 細胞は, leucine, KICAのいずれの刺激に 対しても後期相の著明に増大した分泌動態を示した。特に leucineによる後期相分泌の増大は顕著 であり，最大值はDay 0の10倍以上に達した。同様に KICAの最大刺激効果も Day 0 の 4 倍の 増加を示した (Figs. 3 A, 3 B)。

（2）Glucose 単独培養 B 細胞のインスリン分泌動態

a) Glucoseの効果： 7 日間 glucose $5.5 \mathrm{mM}$ 単独培養した B 細胞は, glucose $16.7 \mathrm{mM}$ 刺激に 対する分泌応答性を殆んど消失していた。しかし，forskolinあるいはIBMXの添加は後期相分泌 を増大させた (Fig. 4 A)。

b ）Leucine および2-ketoisocaproateの効果： Glucose 単独培養 B 細胞の Day 7 におるleucine $10 \mathrm{mM}$ および KICA $10 \mathrm{mM}$ 刺激によるインスリン分泌応答は，Day 0 の培養 $\mathrm{B}$ 細胞におけるの と同程度の低い分泌レベルを示すにすぎなかった（Fig. 4 B)。

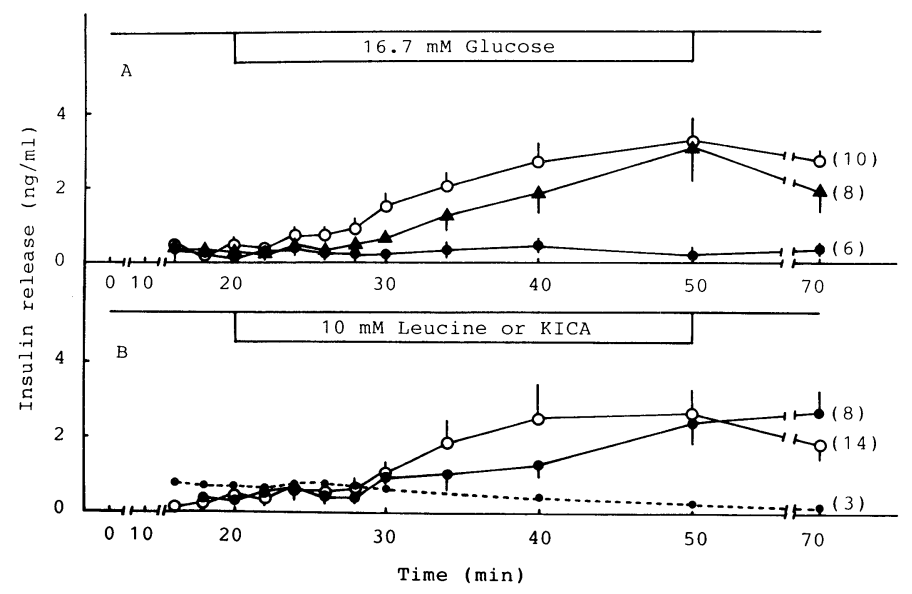

Fig. 4. Time course of insulin release with a square-wave stimulation by glucose, leucine or 2-ketoisocaproate (KICA).

Monolayer islet cells that had been cultured for 7 days with $5.5 \mathrm{mM}$ glucose alone were exposed to $16.7 \mathrm{mM}$ glucose (A), and leucine or 2-ketoisocaproate at $10 \mathrm{mM}(\mathrm{B})$ for 30 min after the first 20 -min perifusion with nonstimulatory medium. Each point is the mean \pm SEM of $3 \sim 14$ experiments shown in the figure. [A: $\longrightarrow 16.7 \mathrm{mM}$ glucose, $\longrightarrow 16.7 \mathrm{mM}$ glucose $+10 \mu \mathrm{M}$ forskolin, $\longrightarrow 16.7 \mathrm{mM}$ glucose $+1 \mathrm{mM}$ 3-isobutyl1-methylxanthine; B: $\bullet-\longrightarrow$ no stimulus, $\longrightarrow 10 \mathrm{mM}$ leucine, $\square \longrightarrow 10 \mathrm{mM} \mathrm{2-}$ ketoisocaproate (KICA)]

2. $\mathrm{cAMP}$ 放出および細胞内 $\mathrm{cAMP}$ 量

Day 0の培養細胞では, $1 \mathrm{mM}$ IBMX, $10 \mu \mathrm{M}$ forskolin 存在下での glucose $16.7 \mathrm{mM}$ 刺激による cAMP放出は, glucose $16.7 \mathrm{mM}$ 単独刺激の9.7，34.1倍に増大した。一方，2-deoxy-2-fluoroglucose 添加培養した B 細胞の glucose $16.7 \mathrm{mM}$ 存在下での cAMP放出は, Day 0の25.2倍の高值を 示し，また，このcAMP放出はIBMX, forskolinの添加によって8.4，41.2倍に増大した。細胞内 
cAMP量については，Day 0 と2-deoxy-2-fluoroglucase 添加培養B 細胞（Day 7 ）の間に大きな 差異はないが, IBMX, forskolin 存在下において前者では14.8，45.0倍に，後者では13.5，37.3倍 と，それぞれ細胞内 cAMP 量の著明な増大が認められた（Table 1 )。

Table 1. Effect of 2-deoxy-2-fluoroglucose on the recovery of cAMP in cells and incubation medium.

\begin{tabular}{|c|c|c|c|c|}
\hline \multirow[t]{2}{*}{ Stimulus (mM) } & \multicolumn{2}{|c|}{$\begin{array}{c}\text { CAMP release } \\
(\mathrm{fmol} / \mu \mathrm{g} \text { DNA } / 30 \mathrm{~min})\end{array}$} & \multicolumn{2}{|c|}{ 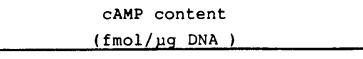 } \\
\hline & day 0 & day 7 & day 0 & day 7 \\
\hline Glc 0 & $55.6 \pm 3.1$ & $1103.1 \pm 204.7$ & $253.4 \pm 14.5$ & $334.7 \pm 29.8$ \\
\hline Gle 16.7 & $68.2 \pm 15.3$ & $1721.3 \pm 89.7$ & $252.9 \pm 12.7$ & $354.1 \pm 6.9$ \\
\hline $\begin{array}{r}\text { Glc } 16.7+\text { forskolin } \\
0.01\end{array}$ & $2328.4 \pm 57.7^{\star}$ & $70899.0 \pm 8359.9^{\star}$ & $11383.8 \pm 1387.0^{\star}$ & $13210.1 \pm 1008.5^{\star}$ \\
\hline GlC $16.7+\operatorname{IBMX} 1.0$ & $664.6 \pm 45.6^{\star}$ & $14459.8 \pm 1090.8^{\star}$ & $3735.5 \pm 336.1^{\star}$ & $4778.0 \pm 487.2^{\star}$ \\
\hline
\end{tabular}

The results are shown as the mean \pm SEM of 6 experiments.

*, p $<0.001$ (against each stimulating level induced with $16.7 \mathrm{mM}$ glucose at culture day 0 or day 7).

The culture DNA contents were $6.03 \pm 0.20 \mu \mathrm{g} /$ culture $(\mathrm{n}=6)$ and $1.44 \pm 0.17 \mu \mathrm{g} / \mathrm{culture}$ $(n=6)$ at day 0 and day 7 , respectively.

\section{IV 考}

本研究において，著者らは灌流実験によって培養膵 B 細胞の機能変化をより正確に捉え，未成熟 な分泌機能を示す B 細胞が2-deoxy-2-fluoroglucoseの添加培養によって成熟ラット茀島に類似し た二相性の分泌応答能を獲得していることを実証した。新生児膵の低反応性インスリン分泌は, 静 置実験同様，腪単層培養細胞の灌流実験においても確認され，細胞形態，in vivoあるいは in vitro

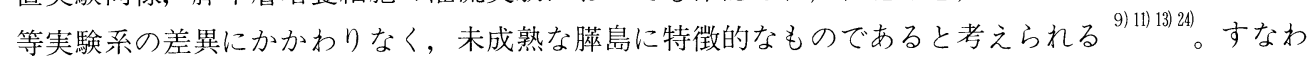
ち，培養初期の単層培養 B 細胞に認められた glucose 刺激に対応する一相性の分泌応答は, in vivo 実験，あるいは荤組織片の灌流実験の成績とも一致した ${ }^{1617200}$ 。従来, 新生児膵の低反応性分泌応答 については B 細胞内 cAMP 濃度および五炭糖回路のglucose 代謝の減少と関係しているものと考え られてきた ${ }^{11037}$ 。特に, adenylate cyclase を直接活性化する forskolin, あるいはphosphodiesteraseを阻害するIBMXの添加によって，Day 0の B 細胞が glucose 刺激に対応して二相性分泌を示 した成績は，新生児膵 $\mathrm{B}$ 細胞が glucose 刺激のみではインスリン分泌を誘起し，且つそれを持続す るための有効な細胞内 $\mathrm{cAMP}$ 濃度を保持し得ないという従来の見解を支持するものである ${ }^{10}{ }^{38}$ 。同 様に，Day 0においてleucine，KICA 刺激が低反応性であったことは，これら栄養物質と glucose の代謝経路が異なっていることより, 新生児 $\mathrm{B}$ 細胞の低反応性分泌応答については, 糖代謝のみな らずアミノ酸異化の全般的低下からも併世考えられるべきである ${ }^{37}$ 。

成熟膵島が, glucose, leucine あるいは KICA 刺激期間にスパイク様初期相と持続的な後期相か

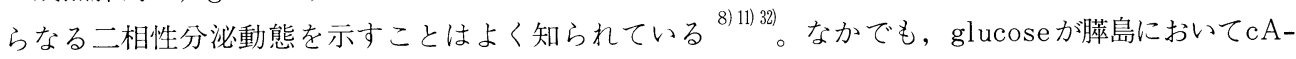
MP 産生作用を有するために, glucose と cAMPの両者は不可分に結びついてインスリン分泌刺激 機序の解明，また一方，㬳島培養に際してはその細胞機能および細胞形態に及ぼす有益な作用と関 連させて議論されてきた ${ }^{26)}$ 。Rabinovitch et al. ${ }^{27}$ は高濃度 glucose, IBMX あるいはBr・cAMP 等, 
細胞内 $\mathrm{cAMP}$ 量を增大させる物質が, 胎児・新生児 $\mathrm{B}$ 細胞の機能維持・増殖に有益であることを報 告した。著者らも2-deoxyglucose, 2-deoxy-2-fluoroglucose 添加培養B 細胞の生存・機能京進が 細胞内 $\mathrm{cAMP}$ の増大と関連している可能性を示唆した ${ }^{39}$ 40)。しかしながら, 胎児・新生児の未成熟 な機能を成熟化に導く因子，およびその機序については現在，尚明らかではない。

本灌流実験の成績に示される様に，2-deoxy-2-fluoroglucose 添加培養した Day 7 の B 細胞が, glucose 刺激に対し二相性分泌動態を示し，成熟膵島に類似した分泌機能を獲得していることは明 らかである。また，このglucose 感受性は, IBMX 添加による影響を受けなかった。これらの結果 は，2-deoxy-2-fluoroglucose 添加培養 B 細胞が glucose 刺激に対して後期相分泌を誘起するに充 分なadenylate cyclaseの活性化をはじめ，成熟腪島に特徵的な分泌機構を備えていることを示唆 している。特にcAMPの関与は，Day 7 の培養細胞の glucose $16.7 \mathrm{mM}$ 刺激下での cAMP 放出が, Day 0のIBMX 存在下でのそれと比べ2.6倍にも増大していたことによって支持される。しかし， インスリン分泌，cAMP放出あるいは細胞内cAMP 量が，forskolin，IBMX 存在下において，必ず しも平行関係になかったことは，インスリン分泌が $\mathrm{cAMP}$ のみなず他の因子によって調節されて いることを示唆している。また，この cAMP 濃度の上昇は，䓠島細胞の再凝集および細胞の伸展に

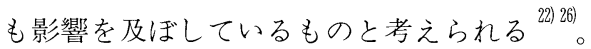

捸食後の栄養物質の血中濃度は，矩形的に急激な增大を示すのではなく緩徐に上昇する。この in vivoの刺激条件に類似した glucose 濃度勾配刺激法は，インスリン分泌閾値や用量反応曲線を求 める上で有用である ${ }^{4)}$ 18)。2-Deoxy-2-fluoroglucose 添加培養 B 細胞は, glucose 濃度勾配刺激に対 応して用量反応的にインスリンを分泌した。インスリン分泌閾值は約 $4 \mathrm{mM}$-glucose, "Km" 值は 8 mM-glucose を示し，この成績は成熟ラット腪島並びに2-deoxy-2-fluoroglucose 添加培養細胞の

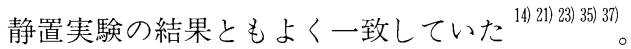

一方，2-deoxy-2-fluoroglucose 添加培養は leucine, KICA 刺激に対しても glucose 刺激におけ るのと同様，後期相の高いインスリン分泌応答を示した。この2-deoxy-2-fluoroglucose 添加培養 B 細胞の glutamine 代謝が， leucine あるいは KICA 存在下で艺進することは既に報告したが ${ }^{37)}$ ，灌 流実験における後期相分泌の出現とglutamine 代謝の成績からみて, 2-deoxy-2-fluoroglucose 添 加培養は B 細胞のアミノ酸異化を増大させることにより, 代謝エネルギーを補充し，インスリン分 泌を誘起している可能性が推察される。このことは，成熟ラット膵島にみられる leucine および KICAのインスリン分泌刺激効果が glutamine 代謝の克進と関連しているというSener et al. ${ }^{28)}$ の考之 ともよく一致している。

以上述べた様に, 内分泌細胞を選択的に生存させ, 且つ B 細胞機能の成熟化を刺激する2-deoxy2-fluoroglucoseの効果はその同族体である2-deoxyglucoseの効果と類似していた ${ }^{38)}$ ここれらデオ キシ糖は細胞内で糖ヌクレオチドへ変換され，糖蛋白質・糖脂質の糖鎖合成を阻害することが知ら れている。近年 2-deoxy-2-fluoroglucoseによるFriend 白血球細胞の造血能の増大 ${ }^{2)}$, また perineris cultifera 卵母細胞の成熟化に伴うGDP-mannoseの減少 ${ }^{3)}$ 等, 糖鎖の細胞分化に及ぼす効果 が次第に明らかにされつつあるが，2-deoxy-2-fluoroglucoseによる B 細胞機能の成熟化機構にお ける糖蛋白質・糖脂質の関与についての検討は今後の研究課題である。

\section{V 結 語}

本研究において，著者らは灌流実験によって単層培養膵 B 細胞のインスリン分泌機能の変化を動 
的に把握し，未成熟な低反応性分泌応答を示す新生児膵 B 細胞が2-deoxy-2-fluoroglucose 添加培 養によって, glucose, leucine および2-ketoi socaproate 刺激に対し成熟㬸様の二相性分泌応答能を 獲得していることを実証した。また，glucose 濃度勾配刺激法より算出した分泌間值並じに "Km" 值は静置実験から得られた成績とよく一致した。加えて, 2-deoxy-2-fluoroglucose 添加培養細胞 の cAMP 応答の増大を認めた。

本研究に用いた新生児荤単層培養細胞は，ホルモン分泌機能の研究に有用であると考えられる。

\section{交献}

1) Andersson, A. and Hellerström, C.: Metabolic characteristics of isolated pancreatic islets in tissue culture. Diabetes, 21 (supple 2): 546-554, $1972 . \quad 2$ 2) Bosman, G.J. C.G.M., Boer, P. and Steyn-Parvé, E.P.: Inhibitors of protein glycosylation inhibit the differentiation of Friend erythroleukemia cells. Biochim. Biophys. Acta, 696: 285-289, 1982.

3) Bulet, P., Hoflack, B., Porchet, M. and Verbert, A.: Study of the conversion of GDPmannose into GDP-fucose in nereids: A biochemical marker of oocyte maturation. Eur. J. Biochem., 144: 255-259, $1984 . \quad$ 4) Curry, D.L.: Insulin secretory dynamics in response to slow-rise and square-wave stimuli. Am. J. Physiol., 221: 324-328, 1971.

5) De Gasparo, M., Milner, G.R., Noris, P.D. and Milner, R.D.G.: Effect of glucose and amino acids on foetal rat pancreatic growth and insulin secretion in vitro. J. Endocr., 77: 241-248, $1978 . \quad$ 6) Fujimoto, W.Y., Teague, J. and Williams, R.H.: Fibroblast monolayer cultures in scintillation counting vials: Metabolic and growth experiments using radioisotopes and a microfluorometric DNA assay. In Vitro, 13: 237-244, 1977.

7) Fujimoto, W.Y.: Purification of neonatal rat pancreatic monolayer cultures for endocrine cells. Proc. Soc. Exp. Biol. Med., 162: 241-244, 1979.

8) Gerber, P.P.G., Trimble, E.R., Wollheim, C.B., Renold, A.E. and Miller, R.E.: Glucose and cyclic AMP as stimulators of somatostatin and insulin secretion from the isolated, perifused rat pancreas: A quantitative study. Diabetes, 30: 40-44, $1981 . \quad 9$ 9) Grill, V., Asplund, K., Hellerström, C. and Cerasi, E.: Decreased cyclic AMP and insulin response to glucose in isolated islets of neonatal rats. Diabetes, 24: 746-752, $1975 . \quad 10$ ) Grill, V., Lake, W. and Freinkel, N.: Generalized diminition in the response to nutrients as insulinreleasing agents during the early neonatal period in the rat. Diabetes, 30: 56-63, 1981.

11) Grodsky, G.M., Batts, A.A., Bennett, L.L., Vella, C., McWilliams, N.B. and Smith, D.F.: Effects of carbohydrates on secretion of insulin from isolated rat pancrease. Am. J. Physiol., 205: 638-644, $1963 . \quad$ 12) Heinze, E. and Steinke, J.: Insulin secretion during development: Response of isolated pancreatic islets of fetal, newborn and adult rats to theophylline and arginine. Horm. Metab. Res., 4: 234-236, 1972.

13) Hellerström, C., Lewis, N.J., Borg, H., Johnson, R. and Freinkel, N.: Method for largescale isolation of pancreatic islets by tissue culture of fetal rat pancreas. Diabetes, 28: 769 -776, $1979 . \quad 14)$ Henquin, J.C.: Tolbutamide stimulation and inhibition of insulin release: Studies of the underlying ionic mechanism on isolated rat islets. Diabetologia, 18: $151-160,1980$.

15) Kagawa, S., Wakabayashi, S., Nakao, K., Mimura, K. 
and Matsuoka, A.: Maintenance of pancreatic endocrine cells of the neonatal rat: Part VIEffects of medium with fructose and 2-deoxyglucose. Ind. J. Biochem. Biophys. (in press).

16) Kawazu, S., Kanazawa, Y., Ikeuchi, M., Hayashi, M. and Kosaka, K.: The dynamics of insulin release from monolayer-cultured pancreatic cells in a new perifusion system. Proc. Soc. Exp. Biol. Med., 156: 197-200, 1977.

17) Kikuchi, M., Rabinovitch, A., Blackard, W.G. and Renold, A.E.: Perifusion of pancreas fragments: A system for the study of dynamic aspects of insulin secretion. Diabetes, 23: 550-559, 1974.

18) Kobayashi, K., Ise, H., Tsumura, Y., Kagawa, S. and Matsuoka, A.: A new approach to kinetic analysis of glucose-induced insulin release by Hill's equation. Endocrinol. Japon., 24: 367-373, 1977. 19) Lambert, A.E., Blondel, B., Kanazawa, Y., Orci, L. and Renold, A.E.: Monolayer cell culture of neonatal rat pancreas: Light microscopy and evidence for immunoreactive insulin synthesis and release. Endocrinology, 90: 239-248, 1972.

20) Lavine, R.L., Chick, W.L., Like, A.A. and Makdisi, T.W.: Glucose tolerance and insulin secretion in neonatal and adult mice. Diabetes, 20: 134-139, 1971.

21) Landgraf, R., Kotler-Brajtburg, J. and Matschinsky, F.M.: Kinetics of insulin release from the perfused rat pancreas caused by glucose, glucosamine, and galactose. Proc. Natl. Acad. Sci., U.S.A., 68: 536-540, $1971 . \quad 22)$ Maes, E. and Pipeleers, D.: Effects of glucose and $3^{\prime}, 5^{\prime}$-cyclic adenosine monophosphate upon reaggregation of single pancreatic B-cells. Endocrinology, 114: 2205-2209, 1984.

23) Malaisse, W.J., Sener, A., Herchuelz, A. and Hutton, J.C.: Insulin release: The fuel hypothesis. Metabolism, 28: $373-$ 386, 1979.

24) Minz, D.H., Levey, G.S. and Schenk, A.: Adenosine 3', 5'-cyclic monophosphate and phosphodiesterase activities in isolated fetal and neonatal rat pancreatic islets. Endocrinology, 92: 614-617, 1973.

25) Murakoso, K., Tsumura, Y., Nakao, K., Kagawa, S. and Matsuoka, A.: Effect of alloxan on the incorporation of Dglucose into cultured pancreatic endocrine cells of the rat. Chem. Pharm. Bull., 28: 837842, 1980.26 26) Ohgawara, H., Carroll, R., Hofmann, C., Takahashi, C., Kikuchi, M., Labrecque, A., Hirata, Y. and Steiner, D.F.: Promotion of monolayer formation in cultured whole pancreatic islets by 3-isobutyl-1-methylxanthine. Proc. Natl. Acad. Sci., U.S.A., 75: 1897-1900, $1978 . \quad$ 27) Rabinovitch, A., Quigley, C. and Rechler, M.M.: Growth hormone stimulates islet B-cell replication in neonatal rat pancreatic monolayer cultures. Diabetes, 32: 307-312, $1983 . \quad 28)$ Sener, A., Hutton, J.C. and Malaisse, W.J.: The stimulus-secretion coupling of amino acid - induced insulin release: Synergistic effect of L-glutamine and 2-keto acids upon insulin secretion. Biochim. Biophys. Acta, 677: 32-38, 1981.

29) Shimizu, S., Jha, B., Kagawa, S., Nakao, K., Yoshida, K., Wakabayashi, S. and Matsuoka, A.: The effect of 2-deoxy-D-glucose on insulin release by neonatal rat B cells in culture. Endocrinol. Japon., 30: 255-260, 1983.

30) Shimizu, S., Kagawa, S., Nakao, K., Wakabayashi, S., Mimura, K. and Matsuoka, A.: Effect of iodoacetic acid on maintenance of pancreatic endocrine cells of the neonatal rat. Endocrinol. Japon., 31: 253-261, 1984.

31) Schmidt, M.F.G., Biely, P., Kratky, Z. and Schwarz, T.: Metabolism of 2-deoxy-2-fluoro-D- $\left[{ }^{3} \mathrm{H}\right]$ glucose and 2-deoxy- 
2-fluoro-D $\left[{ }^{3} \mathrm{H}\right]$ mannose in yeast and chick-embryo cells. Eur. J. Biochem., 87: 55-68, 1978. 32) Tomita, T. and Scarpelli, D.G.: Interaction of cyclic AMP and alloxan on insulin secretion in islets perifused in vitro. Endocrinology, 100: 1327-1333, 1977.

33) Wakabayashi, S., Kagawa, S, Nakao, K., Yoshida, K., Mimura, K. and Matsuoka, A.: Maintenance of pancreatic endocrine cells of the neonatal rat: Part-IV The effect of 3-amino3-deoxyglucose. Endocrinol. Japon., 31: 657-664, 1984.

34) Wakabayashi, S., Kagawa, S., Nakao, K., Mimura, K. and Matsuoka, A.: Maintenance of neonatal rat B cells in glucose-depleted medium: Effect of medium with galactose and 2-deoxyglucose. J. Endocr., 103: 377-381, $1984 . \quad 35)$ Wakabayashi, S., Kagawa, S., Nakao, K., Mimura, K. and Matsuoka, A.: Maintenance of neonatal endocrine cells of the rat: Effect of 2-deoxy-2-fluoroglucose on the responses to glucose, leucine and 2-ketoisocaproate. Horm. Metab. Res., 16: 672-673, 1984 . 36) 若林 茂, 香川昌平, 中尾啓子, 三村 幸一, 松岡 瑛：新生児ラット腪培養 B 細胞の機能維持, 医学のあゆみ, 132: 596-597, 1985.

37) 若林 茂, 香川昌平, 中尾啓子, 松岡 瑛：新生児ラット胹単層培養 $\mathrm{B}$ 細胞機能の成熟に及ぼす 2-deoxy-2-Fluoroglucoseの効果, 日内分泌会誌， 61: 592-604, 1985.

38）若林 茂,

香川昌平, 中尾啓子, 松岡 瑛：2-デオキシグルコースおよびヨード酢酸による新生児ラット脇培盖 B 細 胞の機能維持に関する研究, 兵医大学会誌. (印刷中).

39) Yoshida, K., Kagawa, S., Murakoso, K. and Matsuoka, A.: Effect of 2-deoxy-D-glucose on maintenance in culture of neonatal B cell of rat. In Vitro, 20: 756-762, $1984 . \quad 40)$ Yoshida, K., Kagawa, S., Murakoso, K., Nakao, K., Shimizu, S., Wakabayashi, S., Haito, K., Tanaka, N., Jha, B. and Matsuoka, A.: Maintenance of neonatal endocrine cells of the rat: Part-I Effects of 2deoxyglucose and 2-deoxy-2-fluoroglucose. Horm. Metab. Res., 16: 120-124, 1984.

（受付日 :'85,6。10) 